\title{
Evaluating Attitudes in News Text: Appraisal in Critical Discourse Study
}

\author{
Chalimah \\ Universitas Sebelas Maret \\ Surakarta, Indonesia \\ chalimahstkipjb@gmail.com \\ Djatmika \\ Universitas Sebelas Maret \\ Surakarta, Indonesia \\ djatmika26@gmail.com
}

\author{
Riyadi Santosa \\ Universitas Sebelas Maret \\ Surakarta, Indonesia \\ rst@uns.ac.id \\ Tri Wiratno \\ Universitas Sebelas Maret \\ Surakarta, Indonesia \\ wiratno.tri@gmail.com
}

\begin{abstract}
The discrimination in religious affair has become a global problem which is very essential to be noticed in a linguistic way, especially for conflict between Israel and Palestinians on Gaza which keep on happening for many years. This study contributes in critical discourse study by interpreting the discourse to understand social culture from the linguistic perspectives by analyzing text through systemic functional linguistics: appraisal system. The gap of the study which differs from other researches is namely analyzing the news item from Cable News Network (CNN) dated in April in 2018 in the religious case investigated in the aspects of language evaluation. The study focuses on attitude: affect to find out the classification of feeling used in the text to construe the cultural aspects. The design of the study is descriptive qualitative. There are two kinds of validity implemented in this study. They are expert validity and source validity. The expert validity is reached through the comments given by the experts. The findings of the study show that the text consists of appraisal which shows unhappiness: antipathy $(23.81 \%)$; security: confidence $(\mathbf{2 3 . 8 1 \%})$; dissatisfaction: displeasure $(\mathbf{1 4 . 2 9 \% )}$; insecurity: disquiet $(9.52 \%)$; behavioral surge $(9.52 \%)$; insecurity: surprise $(4.76 \%)$; inclination (4.76\%); security: trust $(4.76 \%)$; unhappiness: misery $(4.76 \%)$. The appraisal can show that the text has applied negative feeling on unhappiness: antipathy of Israel to Palestinians and security: confidence between them who both of them feel strongly confident in their each deed.
\end{abstract}

Keywords_critical; discourse; appraisal; attitude; culture

\section{INTRODUCTION}

The discrimination still happens in treating countries with the reason of different religions. It is very essential to investigate the discrimination between Palestinians and Israel in linguistic point of view. This study gives a great contribution in analyzing text through systemic functional grammar: appraisal. The appraisal convinces as the way to evaluate the lexis and the structure used in text to know the kinds of feeling expressed. There are three reasons why appraisal can show the meaning of the text well (Martin and White, 2005: 10-11) namely: (1) appraisal realizes the attitude through a phrase of discourse; (2) the realization of attitude is in grammatical categories such as an adjective (epithet), a verb (process), an adverb (comment adjunct); (3) there is the question of grammatical metaphor such as nominalization and modality.

There is a very close relation between critical discourse analysis and systemic functional linguistic: appraisal. There are relations between Critical Discourse Analysis (CDA) and Systemic Functional Linguistics (SFL) stated in (Young and Harrison, 2004: 1) that become the focus of linguistic investigation, namely: both CDA and SFL are used to give a view on language as a social construction by seeing the language role in society and see the way in delivering the language, both CDA and SFL see the language which can influence the context and vice versa, how the context influences the language, both CDA and SFL give attention to the semantic aspect seen from the cultural aspect and the historical aspect.

A large number of researches have conducted a study on appraisal and there is still a gap found. Dong (2006) investigated appraisal on students' writing in blog; Pascual and Unger (2010) focused on appraisal in proposals which got international grant; Isaac (2012) analyzed arguments of ten international non native speaker who uses English for academic purposes by using appraisal theory; Hadidi and Parvin (2015) conducted a study on appraisal in novel; Wei,Wherrity, and Zhang (2015) reviewed appraisal theory from the current research in China and abroad; Haristyanti (2015) saw appraisal used by Barack Obama in his speech; Drasovean and Tagg (2015) studied on online participants' comments. The study on appraisal by analyzing newspaper online in religion context in critical discourse analysis has not been done and it becomes the gap of the study.

\section{LITERATURE REVIEWS}

The literature reviews consist of aim of the critical discourse study to make sure that this study can meet the proper aim and the relation of appraisal with critical discourse analysis to convince that appraisal can be a referential theory to analyze the data. 


\section{A. Aim of Critical Discourse Study/Analysis}

There are some aims of critical discourse analysis that should be known such as: (1) to make the issue of discrimination accepted by the world to protect the marginal group; (2) to make the world understand the social and political problem; (3) to conduct the empirical study with applicable theory; (4) to explain the social interaction and social structure; (5) to determine, to confirm, and to against the abuse of power and domination (Van Dijk, 2001: 353).

\section{B. Relation of Systemic Functional Linguistics: Appraisal and Critical Discourse Analysis}

Young and Harrison (2004:2) state that Systemic Functional Linguistics (SFL) and Critical Discourse Analysis (CDA) have a great relation. SFL is as one way to explain and describe the relation of theory and application in detail by looking at the relation between language and society, language and power, language and social change. This is the way which can convince that SFL can dig the relation between power and ideology in detail through discourse analysis in real language context by giving explicit, transparent, and right result.

SFL has three general social functions. The first is interpersonal. The interpersonal function helps to see the relationship. The second is ideational. The ideational function helps to see the experience. The last is textual. The textual function assists to organize the text. In this study, SFL can explore the interpersonal function: appraisal to analyze the negotiating attitudes in depth. (Martin and Rose, 2007:7).

Appraisal is a discourse semantic resource which construes interpersonal meaning. Appraisal has three domains namely attitude, engagement, and graduation (Martin and White, 2005: 35). This study focuses on the attitudes which evaluate language to show the kinds of feeling or affect.

Martin and Rose (2007:63-64) have given some ways to help in classifying the affect as in the following way:

(1) Determine if the feelings are in positive or negative one. For example: the girl is glad (positive); the girl is sad (negative).

(2) Determine whether the feelings show an emotion or a mental state. For example: the man smiled (behavioral); the man felt happy (mental).

(3) Determine if the feelings show the conscious reaction to other or undirected mood which shows uncertainty why the people feel that way. For example: the boy likes the professor/the professor pleases the boy (reaction to other); the boy was happy (undirected mood)

(4) Determine whether the feelings are graded in lower or higher level. For example: the girl likes the gift (low); the girl loves the gift (median); the girl adores the gift (high)

(5) Determine if the feelings involve intention (unreal) or reaction (real). For example: the girl likes the gift (real: the gift is on her hand); the girl wants the gift (unreal: there is a will to get the gift)

(6) Determine the group of emotions into three kinds un/happiness, in/security, and dissatisfaction/satisfaction. For example: she laughed/she cried (un/happiness); she was anxious/she was confident (in/security); she paid attention/she yawned (dissatisfaction/satisfaction)

\section{METHODS}

There are two parts explored in the method. They are research design and validity with reliability.

\section{A. Research Design}

This study applies the descriptive qualitative. The data are taken from an international newspaper online named Cable News Network (CNN) dated in April in 2018 reported by Ian Lee, Abeer Salman and Ameera Ahmed downloaded from https://edition.cnn.com/2018/04/13/middleeast/gaza-israelborder-protests-intl/index.html. The title of the news genre is '1 Palestinian killed, nearly 1,000 injured in latest Gaza protests, Palestinian officials say'. The data are analyzed by using SFL: appraisal. This study limits the investigation on the affect only to find out the kinds of feelings to make interpretation of functional meaning and to determine the social culture of the participants. The analysis of affect is seen from the lexis chosen.

\section{B. Validity and Reliability}

There are two kinds of validity used in this research. The first is expert validity. The analysis of the data pays attention to the expert's suggestion who knows well about the appraisal theory. The second is source validity. This study refers to three referential theories given by Martin and White (2005), Martin and Rose (2007) who explore the theory of appraisal in detail, and also Thompson (2014) who gives further examples on grammatical metaphor which has a relation with the affect.

The reliability is also reached from the three sources. This study classifies the lexis by considering the theories stated in three theories explained by Martin and White (2005), Martin and Rose (2007), and Thompson (2014). The data are reliable when it is suitable with the classification and theory stated in the three theories stated.

\section{RESEARCH FINDINGS AND DISCUSSION}

The data are analyzed based on the affect classification proposed by Martin and Rose (2007:63-64) and also pay attention to the appraisal theory stated by Martin and White (2005) and Thompson (2014). The classification and the description of findings are further explained as the following:

TABLE I. APPRAISAL IN INFORMATION 1

\begin{tabular}{|c|c|c|c|}
\hline $\begin{array}{c}\text { Affect } \\
\text { Classification } \\
\end{array}$ & Realization of Lexis & $\begin{array}{c}\text { Kinds of } \\
\text { Feeling }\end{array}$ & $\begin{array}{c}\text { Descriptive } \\
\text { Information } \\
\end{array}$ \\
\hline $\begin{array}{l}\text { Insecurity: } \\
\text { disquiet }\end{array}$ & $\begin{array}{l}\text { Israeli soldiers stand } \\
\text { as } \quad \text { Palestinian } \\
\text { protesters gather along } \\
\text { the Gaza-Israel border } \\
\text { fence on Friday }\end{array}$ & Negative & $\begin{array}{l}\text { Negative feeling } \\
\text { is felt by Israeli } \\
\text { troops on } \\
\text { Palestinians }\end{array}$ \\
\hline
\end{tabular}

BUDI DN-LPDP Republic of Indonesia 
The datum shows that the lexis stand is considered in the group emotion as insecurity because stand here means: restless. The Israeli soldiers feel insecure so that they decide to stand to protect Gaza from Palestinian. The lexis stand belongs to real affect as it involves reaction and it also a part of metaphorical grammar which has a function to strengthen the words.

TABLE II. APPRAISAL IN INFORMATION 2

\begin{tabular}{|l|l|l|l|}
\hline \multicolumn{1}{|c|}{$\begin{array}{c}\text { Affect } \\
\text { Classification }\end{array}$} & \multicolumn{1}{|c|}{ Realization of Lexis } & $\begin{array}{l}\text { Kinds of } \\
\text { Feeling }\end{array}$ & \multicolumn{1}{c|}{$\begin{array}{c}\text { Descriptive } \\
\text { Information }\end{array}$} \\
\hline $\begin{array}{l}\text { Unhappiness: } \\
\text { antipathy and } \\
\text { Dissatisfaction: } \\
\text { displeasure }\end{array}$ & $\begin{array}{l}\text { One Palestinian was } \\
\text { killed and 968 others } \\
\text { injured in Gaza on } \\
\text { Friday, Palestinian } \\
\text { health officials said, as }\end{array}$ & $\begin{array}{l}\text { Negative feeling } \\
\text { is felt by } \\
\text { Palestinians } \\
\text { side. They feel } \\
\text { unhappiness and } \\
\text { displeasure } \\
\text { demonstrated for a } \\
\text { third week along the } \\
\text { border fence between } \\
\text { Gaza and Israel }\end{array}$ & \\
\hline
\end{tabular}

Table II gives information that the lexis was killed and injured includes in the group emotion as unhappiness: antipathy while the lexis demonstrated is as dissatisfaction: displeasure. The lexis was killed and injured shows the reaction to others. The statement can be written in another way: 'one Palestinian was killed/Israel soldiers assassinated one Palestinian'; '968 others injured/Israeli soldiers hurt 968 others'.

TABLE III. APPRAISAL IN INFORMATION 3

\begin{tabular}{|l|l|l|l|}
\hline $\begin{array}{c}\text { Affect } \\
\text { Classification }\end{array}$ & Realization of Lexis & $\begin{array}{l}\text { Kinds of } \\
\text { Feeling }\end{array}$ & $\begin{array}{c}\text { Descriptive } \\
\text { Information }\end{array}$ \\
\hline $\begin{array}{l}\text { Dissatisfaction: } \\
\text { displeasure }\end{array}$ & $\begin{array}{l}\text { The protests, dubbed } \\
\text { "The March of Return" } \\
\text { have resulted in } \\
\text { confrontations } \\
\text { between Palestinians } \\
\text { and Israeli troops }\end{array}$ & $\begin{array}{l}\text { Negative feeling } \\
\text { is felt by in both } \\
\text { Israeli troops } \\
\text { and } \\
\text { Palestinians' } \\
\text { sides. }\end{array}$ \\
\hline
\end{tabular}

Table III shows the affect classification is as real affect because the feeling involves reaction to create confrontation or violence. The negative affect is shown throw the words have resulted in confrontation which express dissatisfaction: displeasure.

TABLE IV. APPRAISAL IN INFORMATION 4

\begin{tabular}{|c|c|c|c|}
\hline $\begin{array}{c}\text { Affect } \\
\text { Classification }\end{array}$ & Realization of Lexis & $\begin{array}{c}\text { Kinds of } \\
\text { Feeling }\end{array}$ & $\begin{array}{c}\text { Descriptive } \\
\text { Information }\end{array}$ \\
\hline $\begin{array}{l}\text { Unhappiness: } \\
\text { antipathy }\end{array}$ & $\begin{array}{l}\text { The Palestinian Health } \\
\text { Ministry said Islam } \\
\text { Hirzallah, 28, was } \\
\text { shot in the stomach } \\
\text { east of Gaza City and } \\
\text { died of his wounds. }\end{array}$ & Negative & $\begin{array}{l}\text { Negative feeling } \\
\text { is felt by } \\
\text { Palestinian in the } \\
\text { form } \\
\text { unhappiness } \\
\text { because of } \\
\text { Israel's antipathy }\end{array}$ \\
\hline
\end{tabular}

The datum belongs to affect classification considered as reaction to other for the lexis was shot and died'. The sentence can be written in another way, such as the Palestinian Health Ministry said Islam Hirzallah, 28, was shot in the stomach east of Gaza City and died of his wounds can be written Israeli troops killed Islam Hirzallah, 28. The negative affect shows negative reaction of unhappiness: antipathy.

TABLE V. APPRAISAL IN INFORMATION 5

\begin{tabular}{|l|l|l|l|}
\hline $\begin{array}{c}\text { Affect } \\
\text { Classification }\end{array}$ & Realization of Lexis & $\begin{array}{l}\text { Kinds of } \\
\text { Feeling }\end{array}$ & \multicolumn{1}{|c|}{$\begin{array}{c}\text { Descriptive } \\
\text { Information }\end{array}$} \\
\hline $\begin{array}{l}\text { Unhappiness: } \\
\text { antipathy }\end{array}$ & $\begin{array}{l}\text { Many of the injuries } \\
\text { were the result of live } \\
\text { ammunition and tear } \\
\text { gas fired by Israeli } \\
\text { soldiers, the ministry } \\
\text { said. }\end{array}$ & $\begin{array}{l}\text { Negative feeling } \\
\text { is felt by } \\
\text { Palestinian in the } \\
\text { form of } \\
\text { unhappiness } \\
\text { because of } \\
\text { Israel's antipathy }\end{array}$ \\
\hline
\end{tabular}

The datum gives information that the affect classification is considered as reaction to other seen from the words the result of live ammunition and tear gas fired. It can be changed into another reaction form with the same meaning such as Israeli troops attacked with live ammunition and tear gas. The negative feeling is included in unhappiness: antipathy as the real affect.

TABLE VI. APPRAISAL IN INFORMATION 6

\begin{tabular}{|c|c|c|c|}
\hline $\begin{array}{c}\text { Affect } \\
\text { Classification }\end{array}$ & Realization of Lexis & $\begin{array}{l}\text { Kinds of } \\
\text { Feeling }\end{array}$ & $\begin{array}{l}\text { Descriptive } \\
\text { Information }\end{array}$ \\
\hline $\begin{array}{l}\text { Insecurity: } \\
\text { surprise }\end{array}$ & $\begin{array}{l}\text { In one incident, } \\
\text { captured on video } \\
\text { released by the } \\
\text { ministry, a paramedic } \\
\text { station set up near the } \\
\text { southern city of Khan } \\
\text { Younis to treat the } \\
\text { wounded was hit by } \\
\text { tear gas. Ten } \\
\text { paramedics were } \\
\text { treated for tear gas } \\
\text { inhalation. }\end{array}$ & Negative & $\begin{array}{l}\text { Negative feeling } \\
\text { of insecurity: } \\
\text { surprise is felt by } \\
\text { Palestinians }\end{array}$ \\
\hline
\end{tabular}

The datum shows the affect classification as real affect in the form of insecurity: surprise. Actually, the paramedics may not be attacked as the rule in war but this situation happens which realizes a shocked or surprised feeling.

TABLE VII. APPRAISAL IN INFORMATION 7

\begin{tabular}{|l|l|l|l|}
\hline $\begin{array}{c}\text { Affect } \\
\text { Classification }\end{array}$ & Realization of Lexis & $\begin{array}{l}\text { Kinds of } \\
\text { Feeling }\end{array}$ & \multicolumn{1}{|c|}{$\begin{array}{c}\text { Descriptive } \\
\text { Information }\end{array}$} \\
\hline $\begin{array}{l}\text { Inclination and } \\
\text { security: trust } \\
\text { and confidence }\end{array}$ & $\begin{array}{l}\text { Palestinian protesters } \\
\text { cover their faces } \\
\text { against teargas during } \\
\text { a protest at the Gaza- } \\
\text { Israel border }\end{array}$ & $\begin{array}{l}\text { Positive } \\
\text { is felt by the } \\
\text { Palestinians to } \\
\text { show their } \\
\text { inclination }\end{array}$ \\
\hline
\end{tabular}

The datum gives a clue that it is the affect classification as reaction to others shown by the use of lexis cover. Moreover, it also shows real affect of inclination brave. The inclination is well described from the words cover their faces against teargas. The positive feeling of security: trust and security: confidence comes up from Palestinians when they are definitely sure that they are in the right side. 
TABLE VIII. APPRAISAL IN INFORMATION 8

\begin{tabular}{|l|l|l|l|}
\hline $\begin{array}{l}\text { Affect } \\
\text { Classification }\end{array}$ & Realization of Lexis & $\begin{array}{l}\text { Kinds of } \\
\text { Feeling }\end{array}$ & $\begin{array}{c}\text { Descriptive } \\
\text { Information }\end{array}$ \\
\hline Security: & $\begin{array}{l}\text { The Israel Defense } \\
\text { confidence }\end{array}$ & $\begin{array}{l}\text { Forces (IDF) said in a } \\
\text { statement that 10,000 }\end{array}$ & $\begin{array}{l}\text { Positive feeling } \\
\text { is felt by Israel } \\
\text { in confidence of } \\
\text { their statement } \\
\text { gathered in fine } \\
\text { and their deed } \\
\text { locations along the } \\
\text { border fence. The IDF } \\
\text { said several attempts to } \\
\text { "harm or breach the } \\
\text { security infrastructure" } \\
\text { along the border had } \\
\text { taken place, including } \\
\text { the detonation of an } \\
\text { explosive device near } \\
\text { the disused crossing } \\
\text { point at Karni, and the } \\
\text { throwing of firebombs. }\end{array}$ \\
\end{tabular}

The datum gives information that the affect classification is security: confidence noticed from the lexis said in a statement and said. The data describes that Israel is confident in giving statement and in doing the action because it harms their side.

TABLE IX. APPRAISAL IN INFORMATION 9

\begin{tabular}{|l|l|l|l|}
\hline $\begin{array}{c}\text { Affect } \\
\text { Classification }\end{array}$ & Realization of Lexis & $\begin{array}{l}\text { Kinds of } \\
\text { Feeling }\end{array}$ & \multicolumn{1}{|c|}{$\begin{array}{c}\text { Descriptive } \\
\text { Information }\end{array}$} \\
\hline $\begin{array}{l}\text { Security: } \\
\text { confidence }\end{array}$ & $\begin{array}{l}\text { The IDF said it was } \\
\text { responding with what } \\
\text { it called riot dispersal } \\
\text { means, and that it was } \\
\text { firing in accordance } \\
\text { with the rules of } \\
\text { engagement }\end{array}$ & $\begin{array}{l}\text { Positive feeling } \\
\text { is felt by Israel in } \\
\text { confidence of } \\
\text { their statement } \\
\text { and their deed }\end{array}$ \\
\end{tabular}

The datum shows that the affect classification is considered in the group of emotion as security: confidence. The lexis said shows that Israel wants to give explanation with verbal sign that what has been done has a right reason in accordance with the rules of engagement.

TABLE X. APPRAISAL IN INFORMATION 10

\begin{tabular}{|l|l|l|l|}
\hline \multicolumn{1}{|c|}{$\begin{array}{c}\text { Affect } \\
\text { Classification }\end{array}$} & Realization of Lexis & $\begin{array}{l}\text { Kinds of } \\
\text { Feeling }\end{array}$ & \multicolumn{1}{|c|}{$\begin{array}{c}\text { Descriptive } \\
\text { Information }\end{array}$} \\
\hline $\begin{array}{l}\text { Security: } \\
\text { confidence }\end{array}$ & $\begin{array}{l}\text { The Israeli military and } \\
\text { officials have } \\
\text { repeatedly said they } \\
\text { will not allow any } \\
\text { breach of the fence, } \\
\text { and that those who do } \\
\text { not abide by the rules } \\
\text { of engagement will be } \\
\text { shot. }\end{array}$ & $\begin{array}{l}\text { Positive feeling } \\
\text { is felt by Israel in } \\
\text { confidence of } \\
\text { their statement } \\
\text { and their deed }\end{array}$ \\
\hline
\end{tabular}

The datum shows that the affect classification is in the group of emotion of security: confidence. There is also an intensifier used such as repeatedly that makes the emotion stronger. It means that they have a great confidence seen through the real action in the form of giving statement and giving punishment for breaking the rule.

TABLE XI. APPRAISAL IN INFORMATION 11

\begin{tabular}{|l|l|l|l|}
\hline $\begin{array}{c}\text { Affect } \\
\text { Classification }\end{array}$ & Realization of Lexis & $\begin{array}{l}\text { Kinds of } \\
\text { Feeling }\end{array}$ & \multicolumn{1}{|c|}{$\begin{array}{c}\text { Descriptive } \\
\text { Information }\end{array}$} \\
\hline $\begin{array}{l}\text { Unhappiness: } \\
\text { antipathy }\end{array}$ & $\begin{array}{l}\text { In all, 35 Palestinians } \\
\text { have been killed in } \\
\text { Gaza since the latest } \\
\text { round of } \\
\text { demonstrations began } \\
\text { on March 30, according } \\
\text { to a CNN count. } \\
\text { Thousands have been } \\
\text { injured. }\end{array}$ & $\begin{array}{l}\text { Negative feeling } \\
\text { is felt by } \\
\text { Palestinians in } \\
\text { unhappiness } \\
\text { because of } \\
\end{array}$ & $\begin{array}{l}\text { Israel's } \\
\text { antipathy }\end{array}$ \\
& & \\
\end{tabular}

The datum shows that the affect classification is as reaction to other shown by the lexis have been killed and have been injured considered as unhappiness: antipathy. The reaction to other is well described when the words can be changed into another form such as have assassinated and have hurt.

TABLE XII. APPRAISAL IN INFORMATION 12

\begin{tabular}{|l|l|l|l|}
\hline \multicolumn{1}{|c|}{$\begin{array}{c}\text { Affect } \\
\text { Classification }\end{array}$} & \multicolumn{1}{|c|}{ Realization of Lexis } & $\begin{array}{l}\text { Kinds of } \\
\text { Feeling }\end{array}$ & \multicolumn{1}{c|}{$\begin{array}{c}\text { Descriptive } \\
\text { Information }\end{array}$} \\
\hline confirity: & $\begin{array}{l}\text { The goal of the "March } \\
\text { of Return" protests, } \\
\text { Palestinians say, is to } \\
\text { cross the border fence } \\
\text { and return to what they } \\
\text { say are their lands, } \\
\text { which became part of } \\
\text { Israel seven decades } \\
\text { ago. }\end{array}$ & $\begin{array}{l}\text { Positive feeling } \\
\text { is felt by } \\
\text { Palestinian }\end{array}$ & \\
\hline
\end{tabular}

The datum gives information that affect classification shows the group of emotion of security: confidence. The lexis used is say as the verbal sign which has an aim to give confirmation that what Palestinians do is their rights to return or to take the land back.

TABLE XIII. APPRAISAL IN INFORMATION 13

\begin{tabular}{|l|l|l|l|}
\hline \multicolumn{1}{|c|}{$\begin{array}{c}\text { Affect } \\
\text { Classification }\end{array}$} & \multicolumn{1}{|c|}{ Realization of Lexis } & \multicolumn{1}{|c|}{$\begin{array}{c}\text { Kinds of } \\
\text { Feeling }\end{array}$} & \multicolumn{1}{c|}{$\begin{array}{c}\text { Descriptive } \\
\text { Information }\end{array}$} \\
\hline $\begin{array}{l}\text { Unhappiness: } \\
\text { antipathy and } \\
\text { insecurity: } \\
\text { disquiet }\end{array}$ & $\begin{array}{l}\text { Israel blames Hamas } \\
\text { and Islamic Jihad for } \\
\text { the violence, and has } \\
\text { said those killed were } \\
\text { "known terrorists" } \\
\text { while the dead include } \\
\text { some members of }\end{array}$ & $\begin{array}{l}\text { Negative feeling } \\
\text { is felt by Israel } \\
\text { in the form of } \\
\text { unhappiness : } \\
\text { antipathy and } \\
\text { insecurity: } \\
\text { disquiet }\end{array}$ \\
& $\begin{array}{l}\text { Hamas and other } \\
\text { militant groups, a } \\
\text { journalist and other } \\
\text { civilians also have } \\
\text { been killed. The } \\
\text { injured include women } \\
\text { and children. }\end{array}$ & \\
& \multicolumn{3}{|l}{} \\
\hline
\end{tabular}


The datum shows affect classification in unhappiness: antipathy and insecurity: disquiet which show hate and restless when they think Palestinians are a part of terrorists shown by the verbal sign say and the lexis blame which shows behavioral process which shows hate.

TABLE XIV. APPRAISAL IN INFORMATION 14

\begin{tabular}{|c|c|c|c|}
\hline $\begin{array}{c}\text { Affect } \\
\text { Classification }\end{array}$ & Realization of Lexis & $\begin{array}{l}\text { Kinds of } \\
\text { Feeling }\end{array}$ & $\begin{array}{c}\text { Descriptive } \\
\text { Information }\end{array}$ \\
\hline $\begin{array}{l}\text { Behavioral } \\
\text { surge }\end{array}$ & $\begin{array}{l}\text { Hasan Ahsrawi, a } \\
\text { member of the } \\
\text { Palestinian Labor } \\
\text { Organization (PLO) } \\
\text { Executive Committee, } \\
\text { slammed Israel's use } \\
\text { of live-fire in a } \\
\text { statement last week. } \\
\text { "We strongly } \\
\text { condemn Israel's } \\
\text { deliberate and violent } \\
\text { attacks against } \\
\text { unarmed Palestinian } \\
\text { protestors," she said. }\end{array}$ & Negative & $\begin{array}{l}\text { Negative feeling } \\
\text { is felt by } \\
\text { Palestinian on } \\
\text { Israel shown by } \\
\text { behavioral surge }\end{array}$ \\
\hline
\end{tabular}

The affect classification is considered as behavioral surge seen from the lexis used slammed and condemn. Both of them are used to express negative feeling. There is also intensifier used strongly which shows the negative feeling is expressed stronger than usual.

TABLE XV. APPRAISAL IN INFORMATION 15

\begin{tabular}{|c|c|c|c|}
\hline $\begin{array}{c}\text { Affect } \\
\text { Classification }\end{array}$ & Realization of Lexis & $\begin{array}{l}\text { Kinds of } \\
\text { Feeling }\end{array}$ & $\begin{array}{l}\text { Descriptive } \\
\text { Information }\end{array}$ \\
\hline $\begin{array}{l}\text { Behavioral } \\
\text { surge and } \\
\text { Dissatisfaction: } \\
\text { displeasure }\end{array}$ & $\begin{array}{l}\text { Rights group } \\
\text { Amnesty International } \\
\text { called Friday for the } \\
\text { Israeli authorities to } \\
\text { "put an immediate } \\
\text { end to the excessive } \\
\text { and lethal force being } \\
\text { used to suppress } \\
\text { Palestinian } \\
\text { demonstrations in } \\
\text { Gaza." }\end{array}$ & Negative & $\begin{array}{l}\text { Negative feeling } \\
\text { is felt by } \\
\text { Palestinian on } \\
\text { Israel shown by } \\
\text { behavioral surge } \\
\text { and } \\
\text { dissatisfaction: } \\
\text { displeasure at } \\
\text { once }\end{array}$ \\
\hline
\end{tabular}

The datum shows that affect classification as behavioral surge seen from the use of lexis call for which shows dissatisfaction: displeasure. The Palestinians want to end Israel's pressure in Gaza.

TABLE XVI. APPRAISAL IN INFORMATION 16

\begin{tabular}{|c|c|c|c|}
\hline $\begin{array}{c}\text { Affect } \\
\text { Classification }\end{array}$ & Realization of Lexis & $\begin{array}{l}\text { Kinds of } \\
\text { Feeling }\end{array}$ & $\begin{array}{l}\text { Descriptive } \\
\text { Information }\end{array}$ \\
\hline $\begin{array}{l}\text { Unhappiness: } \\
\text { misery }\end{array}$ & $\begin{array}{l}\text { The United Nations } \\
\text { has failed twice to } \\
\text { agree on the release of } \\
\text { a statement addressing } \\
\text { the violence in Gaza. } \\
\text { According to two UN } \\
\text { diplomats, the US } \\
\text { prevented draft } \\
\text { statements from being } \\
\text { issued. }\end{array}$ & Negative & $\begin{array}{l}\text { Negative feeling } \\
\text { is felt by } \\
\text { Palestinians } \\
\text { because UN has } \\
\text { failed to stop the } \\
\text { violence and US } \\
\text { has prevented to } \\
\text { issue the peace } \\
\text { draft in Gaza }\end{array}$ \\
\hline
\end{tabular}

The datum shows that the affect classification is considered as unhappiness: misery or sorrow which is shown by the lexis fail and prevent. There is also intensifier shown by ordinal number twice which describes the event that it has happened more than one and it explores the deep negative feeling inside.

After exploring the data one by one, the number of negative feelings can be derived in the following table XVII.

TABLE XVII. PERCENTAge of AfFect

\begin{tabular}{|l|l|l|}
\hline \multicolumn{1}{|c|}{ Kinds of Affect } & $\begin{array}{c}\text { Total } \\
\text { Number }\end{array}$ & Percentage \\
\hline Unhappiness: antipathy & 5 & $23.81 \%$ \\
\hline Security: confidence & 5 & $23.81 \%$ \\
\hline Dissatisfaction: displeasure & 3 & $14.29 \%$ \\
\hline Insecurity: disquiet & 2 & $9.52 \%$ \\
\hline Behavioral surge & 2 & $9.52 \%$ \\
\hline Insecurity: surprise & 1 & $4.76 \%$ \\
\hline Inclination: bravery & 1 & $4.76 \%$ \\
\hline Security: trust & 1 & $4.76 \%$ \\
\hline Unhappiness: misery & 1 & $4.76 \%$ \\
\hline
\end{tabular}

Considering the findings above related with the other previous researchers' findings is very essential to show the contribution clearly. This study has given new information that appraisal can also be conducted on news item different from the other researches to show the kinds of affect to urge the world to pay attention to the kinds of feeling felt by the marginal sides (Palestinian). It also supports the statements stated by Wei,Wherrity, and Zhang (2015) as one of the proofs that appraisal is an appropriate tool to analyze the attitude and interpersonal meanings both in discourse like what have been conducted by Dong (2006); Pascual and Unger (2010); Isaac (2012); Hadidi and Parvin (2015); Drasovean and Tagg (2015) and in critical discourse conducted by Haristyanti (2015) on Obama's speech.

\section{CONCLUSION}

Based on the findings above, appraisal can show the kinds of feelings or affect clearly. The affect which is the most applicable feeling used in the news shows unhappiness: antipathy and security: confidence $(23.81 \%)$. The datum means that appraisal systems explore the language evaluation to show how much unhappiness and security felt in the news text. There is a big antipathy from Israel to Palestinians and both of them have the same confidence that they are right in their own ways. The second applicable feeling used is dissatisfaction: displeasure (14.29\%). The dissatisfaction: displeasure is mostly felt by Palestinians because there are many of them who are killed and injured and they think the conflict can never meet the end and even the solution to live in peace. There is one information states that both of Palestinian and Israel also feel dissatisfied with the confrontation happens. The third feeling used is insecurity: disquiet and behavioral surge $(9.52 \%)$. Insecurity: disquiet is only felt by Israeli troops while behavioral surge is only shown by Palestinians. The 
affect which shows insecurity: surprise, inclination, security: trust, unhappiness: misery have the same percentage $(4.76 \%)$ which means that the feelings are uncommon to be expressed.

\section{Acknowledgment}

I would like to express my gratitude to BUDI DN-LPDP Republic of Indonesia for the scholarship and the fund to participate in PRASASTI 2018. A lot thanks is also for my lecturers from UNIVERSITAS SEBELAS MARET whose names are written in this paper for the guidance. I also thank STKIP PGRI JOMBANG as the institution where I teach which gives a big support to finish my study.

\section{References}

Dong, A. (2006). How am I doing? The language of appraisal in design. Design Computing and Cognition 06 () Springer, Dordrecht, 385-404. Retrieved from https://www.researchgate.net/publication/226601195_Ho w_am_I_doing_The_language_of_appraisal_in_design

Drasovean, A. \& Tagg, C. (2015). Evaluative language \& its solidarity-building role on TED.com: An Appraisal and Corpus Analysis. Language@Internet. Retrieved from http://oro.open.ac.uk/44604/1/Evaluative\%20Language\% 20 and $\% 20$ Its $\% 20$ Solidarity-

Building\%20Role\%20on\%20TED.pdf

Hadidi, Y., \& Parvin, L.M. (2015). Systemic functional linguistics as interpersonal semantics: Appraisal and attitude in the stylistics analysis of an English novel. International Journal of Linguistics: Macrothink Institute, $\begin{array}{llll}7 . & \text { doi: } & 10.5296 / \text { ijl.v7il.7199 } & \text { or } \\ \text { http//www macrothink org/journal/index php/ijl/article/vi }\end{array}$ ew/7199

Haristyanti, I. (2015). Appraisal in the 2013 inaugural address of President Barack Obama (Thesis). Retrieved from https://media.neliti.com/media/publications/205385appraisal-in-the-2013-inaugural-address.pdf.

NIM. 105110100111058

Isaac, A. (2012). Modelling voice as appraisal and involvement resources: The Portrayal of textual identities and interpersonal relationships in the written stylistic analysis of non-native speaker, International Undergraduates (Doctoral dissertation). Retrieved from http://www.canberra.edu.au/researchrepository/file/62aea 368-2653-479d-a733-ff2c3a4c690c/1/full_text.pdf

Martin, J.R., \& Rose, D. (2007). Working with Discourse: Meaning beyond the Clause. London and New York: Continuum. Retrieved from https://www.scribd.com/doc/153915314/MARTINROSE-2007-Working-With-Discourse-2-Ed

Martin, J.R. \& White, P.R.R. (2005). The Language of evaluation (Appraisal in English). New York: Palgrave Macmillan. Available https://www.palgrave.com/us/book/9781403904096

Pascual, M., \& Unger, L. (2010). Appraisal in the research genres: An analysis of grant proposals by Argentinean researchers. Revista Signos, 43(73), 261-280. Retrieved from

https://www.scribd.com/document/327216927/Pascual-

Unger-2010-Appraisal-in-the-Research-Genres-An-

Analysis-of-Grant-Proposals-by-Argentinean-Researchers

Thompson, G. (2014). Introducing functional grammar. London and New York: Routledge. Available from https://books.google.co.id/books/about/Introducing_Funct ional_Grammar.html?id=pe4cAAAAQBAJ\&redir_esc=y

Van Dijk, A. Teun. (2001). Critical discourse analysis in the handbook of discourse analysis. Edited by Deborah Schiffrin, Deborah Tannen, and Heidi Ehernberger Hamilton. United States of America and United Kingdom: Blackwell Publisher. Retrieved from https://lg411.files. wordpress.com/2013/08/discourseanalysis-full.pdf

Wei, Y., Wherrity, M., \& Zhang, Y. (2015). An analysis of current research on the appraisal theory. Linguistics and Literature Studies, 3(5), 235-239. doi: 10.13189/1ls.2015.030506 http://www.hrpub.org/download/20150831/LLS619304341.pdf

Young, L. \& Harrison, C. (2004). Systemic functional linguistics and critical discourse analysis: Studies in social change. London and New York: Continuum. Available from https://trove.nla.gov.au/work/29320609?q\&versionId=46 674346 